\title{
Instructional Design and Technology Trends in Teacher Education: An AECT Teacher Education Division Special Issue of TechTrends
}

\author{
Jennifer R. Banas ${ }^{1}$ - Drew Polly ${ }^{2}$
}

Published online: 15 January 2016

(C) Association for Educational Communications \& Technology 2016

Traditionally, teacher education has focused on faculty at higher education institutions preparing future teachers and/or training practicing teachers new skills. (e.g., early teacher colleges). In recent years, private entities and corporations have entered the foray of preparing future teachers, as well as evaluating their performance and that of practicing teachers. As the high-stakes climate continues to escalate in Pre-Kindergarten through high school (PK12) settings, so, too, does the degree of accountability for and pressure on those who prepare future teachers (Gonzales 2014; Polly in press). In some states, valueadded assessments have been mandated to empirically evaluate how teacher education programs are linked to PK-12 student achievement (Educational Policy Initiative at Carolina 2014). This data is public and available for everyone to see. Further, additions of performance-based assessments such as edTPA and more rigorous licensure tests have added more straws to the camel's back, forcing teacher education programs to prioritize what should be included and excluded from pre-service teacher program curriculum.

Several documents including the K-12 Horizon Report (New Johnson et al. 2015). the ISTE National Educational Technology Standards for Teachers (NETS-T; ISTE 2008) and Students (NETS-S; ISTE 2007), and the United States National Educational Technology plan (U. S. Department of Education 2010) have put forth bold recommendations

Jennifer R. Banas

j-banas@neiu.edu

1 College of Education, Northeastern Illinois University, Chicago, IL, USA

2 College of Education, University of North Carolina, Charlotte, NC, USA about the role of technology in the teaching and learning processes in both PK-12 schools and teacher education programs. Teacher education programs have long relied on preparing teachers to use technology through the mechanisms of a stand-alone educational technology course, entrusting program faculty to integrate technology into methods or pedagogy courses, or anticipating that practicing teachers will model effective technology integration for pre-service teachers during their clinical practicum settings (Schrum 1999; Smaldino et al. 2014). Despite these best intentions and in light of massive growth in the power and access to technology, Belland (2009) points to unequal growth in teachers' technology integration practices.

This Association for Educational Communications and Technology's Teacher Education Division special issue of Tech Trends celebrates new trends and innovations, and calls attention to the challenges both new and old needing to be addressed. Nesrin Baker leads off the special issue with a historical overview in "Technology and Teacher Education: A Brief Glimpse of the Research and Practice that Have Shaped the Field." Next, Pi-Sui Hsu reveals some of the roadblocks to technology integration in "Examining Current Beliefs, Practices and Barriers about Technology Integration: A Case Study." Craig Shepherd, Doris Bolliger, Tonia Dousay, and Kay Persichitte, in their article "Preparing Teachers for Online Instruction with a Graduate Certificate Program," report on efforts to train pre-service and practicing teachers to be effective online instructors. Swapna Kumar and Heiger Dorner reveal a mentoring model and its useful in "Online Collaborative Mentoring for Technology Integration in PreService Teacher Education." Joseph Winslow, Jeremy Dickerson, Carmen Weaver, and Fair Josey explain how the needs of university educational technology programs and local schools can jointly be addressed in their article, 
"Iterative and Event-based Frameworks for University and School District Technology Professional Development Partnerships." Next, TJ Kopcha, Lu Ding, and Kalianne Neumann discuss the design and implementation of game-based instruction with a sample of pre-service teachers in "Teaching Technology Integration to K-12 Educators: A 'Gamified' Approach.” Also related to gaming, André Denham, Robert Mayben, and Terri Boman discuss bringing gaming to the K-12 classroom in their article, "Integrating Game-Based Learning Initiative: Increasing the Usage of Game-Based Learning Within K-12 Classrooms Through Professional Learning Groups." And finally, Joanne Beriswill, Pamela Bracey, Kathleen Sherman-Morris, Kun Huang, and Sang Joon Lee report on the activities and outcomes of a teacher institute in "Professional Development for Promoting 21st Century Skills and Common Core State Standards in Foreign Language and Social Studies Classrooms."

The articles in this issue represent a small sample of the work being done to support teacher education initiatives through the use of technology in the teaching and learning processes. We hope the authors inspire you to learn more about, to practice in, and to advocate for teachers, technology integration, and the PK-12 audiences they serve.

\section{References}

Belland, B. R. (2009). Using the theory of habitus to move beyond the study of barriers to technology integration. Computers and Education, 52, 353-364.

Educational Policy Initiative at Carolina. (2014). Teacher preparation and performance in North Carolina public schools. Chapel Hill: Author.

Gonzales, G. (2014). Defining teacher-prep accountability. Education Week, 33(24), 28. Retrieved from http://www.edweek.org/ew/ articles/2014/03/12/24gonzalez.h33.html.

Information Society for Technology in Education (ISTE). (2007). National educational technology standards for students. Washington, DC: Author.

Information Society for Technology in Education (ISTE). (2008). National educational technology standards for teachers. Washington, DC: Author.

Johnson, L., Adams Becker, S., Estrada, V., \& Freeman, A. (2015). NMC horizon report: 2015 K-12 edition. Austin: The New Media Consortium.

Polly, D. (in press). Elementary education teacher candidates to design and create learning segments: the case of edTPA task one. In D. Polly (Ed.), Evaluating Teacher Education Programs through Performance-Based Assessments. Hershey, PA: IGI Global.

Schrum, L. (1999). Technology developments for educators: where are we going and how do we get there? Educational Technology Research and Development, 47(4), 83-90.

Smaldino, S., Lowther, D., Russell, J., \& Mims, C. (2014). Instructional technology and media for learning. New York: Pearson.

U. S. Department of Education. (2010). National educational technology plan. Washington, DC: Author. 